\author{
IN THIS ISSUE \\ DUNCAN L. HILCHEY
}

\title{
Cooperatives and alternative food systems initiatives - and more
}

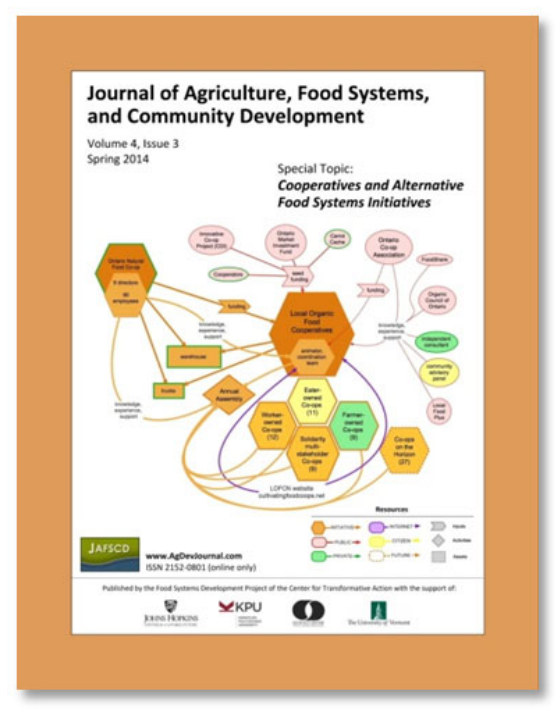

Published online June 25, 2014

Citation: Hilchey, D. L. (2014). Cooperatives and alternative food systems initiatives — and more [Editorial]. Journal of

Agriculture, Food Systems, and Community Development, 4(3), 1-2. http://dx.doi.org/10.5304/jafscd.2014.043.010

Copyright (C) 2014 by New Leaf Associates, Inc.

$\mathrm{I}^{\mathrm{n}}$ n the late 1990s I worked on a project to study small-scale grower cooperatives in the northeastern United States. The existing data on co-ops with annual sales of US $\$ 5$ million or less suggested that they were growing in number, but also that their market share was just a tiny fraction of the growing fruit and vegetable sales in the U.S. We wanted to know more about their challenges and opportunities and to see if they were interested in creating a federation - a co-op of cooperatives. In the study, which included surveys of co-op members, managers, and board members, we found there are many barriers to growth, especially the managers' ability to juggle multiple interests of different types and scales of members, the quality and quantity standards of buyers, and the difficulty of operating in a high cost/low price business. Many small-scale grower co-op managers reported feeling caught between a rock and a hard place; those who reported satisfaction were essentially very gifted at multitasking, managing staff and farmers, and building relationships with buyers.

There was interest in creating a co-op support group - the Northeast Federation of Family-Farm Cooperatives (NEFFCO) - and we discussed ways to achieve as a group of co-ops what was difficult as individual co-ops (such as developing a shared set of operating metrics). We also produced a study report (available at http://www.rurdev.usda.gov/supportdocuments/RR210.pdf). Unfortunately, NEFFCO did not last much beyond the grant period. I wish we had the social networking tools that emerging communities of practice have today that allow them to be lean but productive.

Two people we worked with back then are editors of this issue. Thomas (Tom) Gray, with the USDA

On this issue's cover: This community food system map captures the complex relationships and resources required in a cooperative network. The map was created with the collaboration of the Local Organic Food Co-ops Network coordinator, the paper lead author, and Nourishing Communities researchers, using open-source Visual Understanding Environment software from Tufts University (http://vue.tufts.edu/). See its use in the paper in this issue, Leveraging the Local: Cooperative Food Systems and the Local Organic Food Co-ops Network in Ontario, Canada.

(Image courtesy of Phil Mount) 
Rural Development-Cooperative Programs, arranged a cooperative research agreement that supported the project back in 1998, and Lynda Brushett, with the Cooperative Development Institute, helped us think through the federation concept. In this issue, they provided an American perspective to the papers submitted for the focus on cooperatives and alternative food systems initiatives (AFIs). Tom's editorial on the need for multistakeholder cooperatives is particularly relevant to our North American readership.

Rounding out the editorial team are Colin Anderson of the Centre for Agroecology at Coventry University (UK) and Henk Renting of RUAF, the International Network of Resource Centres on Urban Agriculture and Food Security headquartered in the Netherlands. Henk, a noted authority on AFIs, and Colin, a freshly minted $\mathrm{PhD}$ (University of Manitoba), ensured that we had a sufficient international diversity in our submissions. This was a great group of leaders to work with and the results, as evident in their cogent group editorial entitled "Working Together to Build Cooperative Food Systems," are superlative.

I want to express my appreciation for Colin's leadership. His energy and enthusiasm for cooperative enterprises and his dedication to producing this issue were essential to its completion. We wish him well in his current position at Coventry.

In addition to the nine published papers on the special issue topic, we also offer three columns and an additional open-call paper. In his Metrics from the Field column, Ken Meter discusses a recent study of the co-op community in the U.S. Midwest metropolis of Minneapolis-St. Paul, and the co-ops' collective impact locally. John Ikerd treats us to a very instructive examination of the limits to economic growth in his Economic Pamphleteer column. Rami Zurayk provides a grim but thought-provoking assessment of the new green revolution and its impact on and possible responses from the broad food movement.

We offer one open call paper in this issue, a case study of the Baltimore Food Policy Initiative, by Raychel Santo, Rachel Yong, and Anne Palmer entitled "Collaboration Meets Opportunity: The Baltimore Food Policy Initiative.” Baltimore's thoughtful approaches to addressing some common food security challenges provide an interesting model for other midsized cities to consider.

We round out this issue with two book reviews: Deirdre Helfferich reviews Saving More Than Seeds: Practices and Politics of Seed Saving by Catherine Phillips (Ashgate) in "Seeding a Culture of Remembering." In "Voices of Peasant Farmers from the Margins of the Global Food Crisis," Breann Maxwell and Zulfiya Tursunova review Hungry for Change: Farmers, Food Justice and the Agrarian Question, by A. Haroon AkramLodhi (Fernwood Publishing).

Finally, I want to take this opportunity to announce the launch of our JAFSCD Food Systems Brief series. Food Systems Briefs summarize particularly practical JAFSCD papers into two pages that encapsulate their critical points for quick reference. Papers chosen to be summarized into Food Systems Briefs are ones that practitioners and policy-makers can benefit from on the local or regional level. Food Systems Briefs are free and help fulfill our mission to be a practical publication and, in fact, to effect change in the trenches of the food movement. The first three briefs are available at http://www.agdevjournal.com/ jafscd-food-systems-briefs.html. Individuals interested in preparing a brief will find information on that page as well.

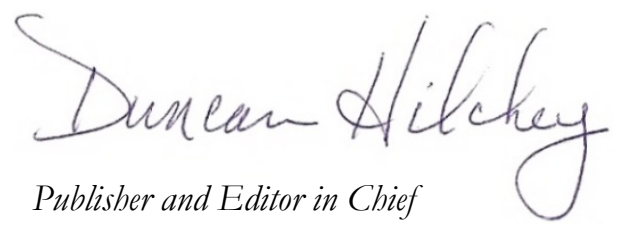

